\title{
LAND SUITABILITY ANALYSIS FOR THE PRODUCTION OF COCOYAM INBENUE STATE, NIGERIA.
}

Gelleh, I. Daniel1*, Okeke U. Henry², Babalogbon, B. Ayodeji², Mangut Y. Silas ${ }^{1}$

${ }^{1}$ National Centre for Remote Sensing Jos, Plateau State Nigeria.

${ }^{2}$ Cooperative Information Network, National Space Research and Development Agency, Obafemi Awolowo University Campus Ile-Ife Osun State, Nigeria.

*Corresponding Author E-mail: gellehdaniels@yahoo.com

This is an open access article distributed under the Creative Commons Attribution License, which permits unrestricted use, distribution, and reproduction in any medium, provided the original work is properly cited.

\section{ARTICLE DETAILS}

\section{Article History:}

Received 26 June 2018 Accepted 2 July 2018 Available online 1 August 2018

\section{ABSTRACT}

Based on the basic principles and assumptions of FAO evaluation approach, suitability evaluation is always for a specific kind of use, meaning that different kinds of land use have different requirements. In this study, the land use suitability is specifically for the production of cocoyam in Benue State, Nigeria. This study aims to identify and delineate areas that best support the growth of cocoyam within the area. In this study, Land-Sat image of 2014 covering the study area was used to classify different land use types in ArcGIS 10.3 software, SRTM data was used to generate slope of study area, soil map of Nigeria was used, and different soil types within the study area was digitized, Multi-Criteria Evaluation was done in other to generate weightage for different factors that were used to produce the suitability map. The various factors that were used include soil, slope, and land use and the weight derived from each of the factors are $0.5,0.3$, and 0.2 respectively. Rainfall is regarded as constant in the area because of the single climatic type covering the small area. The classes established under the soil types include fluvisols, acrisols, alisols, gleysols, and nitisols, which were assigned the relative weights of $0.2667,0.2,0.1333,0.0667$ and 0.3333 respectively. The classes established under the slope include steep slope, strong slope, moderate slope, gentle slope, and nearly level, which were assigned the relative weights $0.0677,0.13,0.2,0.27$ and 0.3333 respectively and the classes established under the land-use factors include settlements, bare-surfaces, cultivated land, vegetation, and wetland, which were assigned the relative weights $0.0667,0.13,0.2,0.27$ and 0.3333 respectively. The result of the computation was classified into four quarters namely $0-25 \%, 26-50 \%, 51-75 \%$, and $76-100 \%$. The results were updated to a newly created field in the attribute data of the GIS layer containing the entire factor data used for suitability evaluation. After computation, SAVMACE sent the results into ArcGIS for symbolization and visualization.

\section{KEYWORDS}

FAO, Suitability, cocoyam, land use, MCE, and SAVMACE.

\section{INTRODUCTION}

The world's population is increasing dramatically, and in order to meet the increasing demand for food, the farming community has to produce more, in order to increase food production and provide food security; crops need to be grown in areas where they are best suited in order to get optimum yields, and this can be done with the aid of land suitability analysis. Based on a study, land suitability analysis is a method of land evaluation, which measures the degree of appropriateness of land for a certain use [1].

Cocoyam otherwise known as Taro is a herbaceous perennial plant belonging to the family Araceae and grown primarily for their edible roots. They are actually of two species namely Colocasia which is basically cultivated as food crops and Xanthosoma species which is comprised of a large spherical corm from which a few large leaves emerge. Cocoyam grows best in fertile, well-draining, sandy loam soil with a $\mathrm{pH}$ between 4.2-7.5. It can be grown in a wide variety of conditions including wetland areas using a system similar to that of rice. Xanthosoma species require temperatures above $21^{\circ} \mathrm{C}\left(69.8^{\circ} \mathrm{F}\right)$ to grow properly. Unlike Colocasia spp, they will not tolerate waterlogging and grow best in deep, well-draining loams with a pH between 5.5 and 6.5 in partial shade. Cocoyam will thrive when planted in full sunlight or partial shade. The plants can survive for short periods at temperatures of $10^{\circ} \mathrm{C}\left(50^{\circ} \mathrm{F}\right)$ but will be damaged or killed by lower temperature.
According to research, the global production of cocoyam has been estimated to be approximately 60 per cent in Africa and 40 per cent in Asia, with little quantities in the Caribbean and Oceania, over an area of 983 million hectares with an average yield of $5.314 \mathrm{mt} / \mathrm{ha}$ [2]. In a lot of developing countries, roots and tubers such as cocoyam, yam, cassava, and sweet potatoes are important crops that generate income and provide food security for the populace.

In Nigeria, cocoyam is cultivated mainly predominantly as annuals, mainly for their edible starchy storage underground stems known as corms and cormels. Cocoyam corms are good sources of carbohydrates with starch that is easily digestible and it's nutritionally superior to its major competitor roots and tubers like cassava and yam in terms of digestibility, contents of crude protein and essential minerals, such as $\mathrm{Ca}, \mathrm{Mg}$, and $\mathrm{P}$. The country maintains the lead among cocoyam producing nations, with an annual production of 4.55 million metric tonnes in 2012, representing 61.2 and $43.1 \%$ total production in West Africa, respectively [3]. Also, in Nigeria cocoyam ranks third after cassava and yam among staple root and tuber crops in terms of importance, total output and production area. It has high economic potential not only as food but also as an agro-industrial raw material for pharmaceutical and livestock industries. This crop is very important and can generate income and provide food security for the populace. 


\subsection{Statement of Problem}

Food is one of the people's basic necessities of life, and government's food production and supply in the State and as such posing threat to food security to the country at large. Cocoyam is actually underexploited in Benue State in as much as it has enormous health benefits over its competitor root crops such as cassava and yam which are eventually given more emphasis. These health benefits are in terms of certain minerals such as $\mathrm{Ca}, \mathrm{Mg}$, and P. Also, it aids digestion more than its competitor crops which include cassava and yam.

The State can increase the production of this root and tuber crop in order to provide food security especially for the teaming population within Benue State and the country at large. This can, however, be done with the aid of a land suitability analysis in order to identify most suitable land for the production of cocoyam within the state.

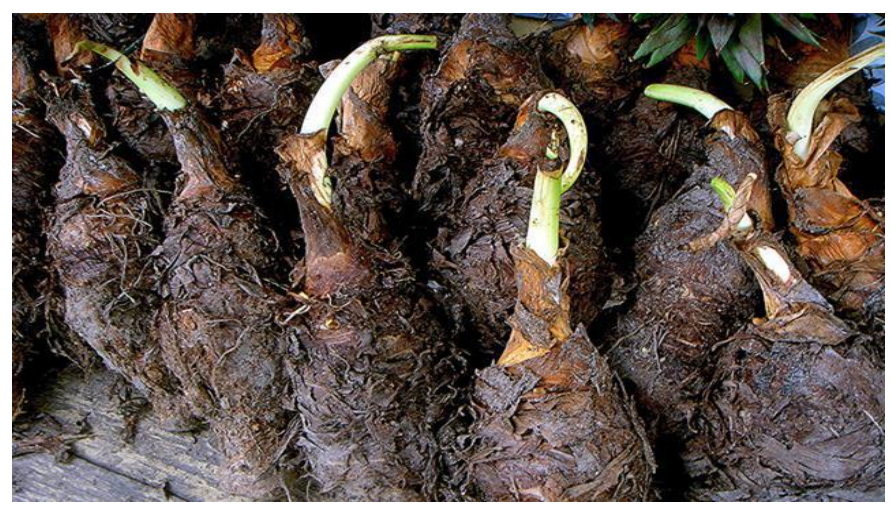

Figure 1: Cocoyam corms

\subsection{Study Area}

Benue is a state in the Mid-belt- region of Nigeria with a population of about 4,253,641 in 2006 census, the State lies on latitude 70 $20^{\prime} \mathrm{N}$ and Longitude $8^{\circ} 45^{\prime} \mathrm{E}$ and has a total area coverage of $34,059 \mathrm{~km}^{2}$. The Study area actually cuts across parts of Gwer-East, Makurdi, Guma, Tarka, Gboko and Buruku Local Government Areas of the State and it lies on Latitudes 8o $0^{\prime} 40.87^{\prime \prime} \mathrm{N}$, 7o $23^{\prime} 33.46^{\prime \prime} \mathrm{N}$ and Longitudes 70 40' $50.87^{\prime \prime} \mathrm{E}, 8^{\circ} 7^{\prime} 35.97^{\prime \prime} \mathrm{E}$.The State is a very rich agricultural region and, some of the crops grown there include potatoes, cassava, soy beans, guinea corn, sesame, maize, rice, groundnuts, yam etc.

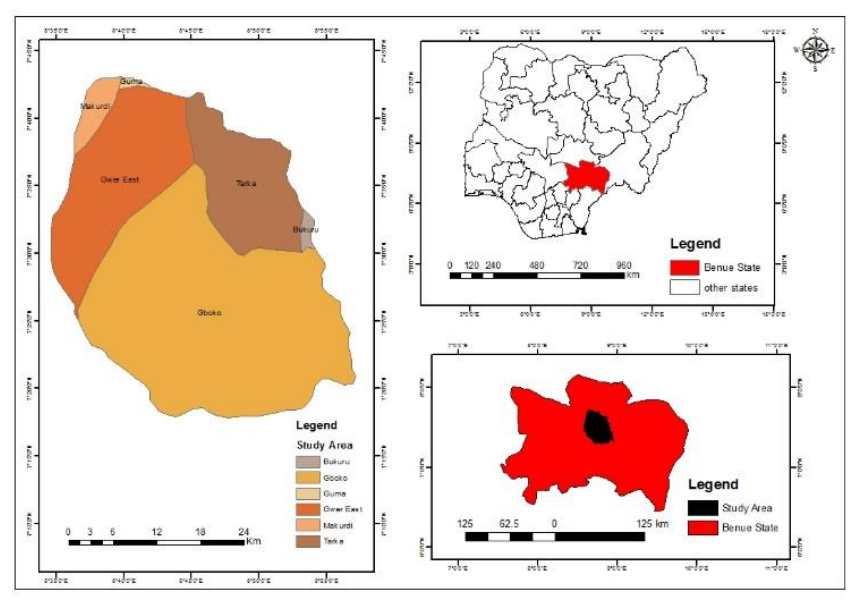

Figure 2: Map of Nigeria Showing Benue State and Study Area.

\subsection{Aim and Objectives}

To identify and delineate areas that can best support the growth of cocoyam within the study area

\subsection{Objectives}

1.Identify the various factors responsible for cultivation of cocoyam within the area.

2.To provide thematic maps of land suitability for the production of cocoyam.

3.Integrate Multi-criteria Evaluation method and GIS to produce a suitability map for cocoyam production. recognition of this fact informs its strenuous efforts always to ensure that foods are available at affordable costs to the populace. Benue State has experienced food shortage as a result of the incessant attacks by Fulani herdsmen on farmers and farmlands in the State, and this has affected the

\subsection{Justification}

The rationale for the choice of land suitability for cocoyam production emanated from the fact that the production of this root and tuber crop within the State has been neglected for long despite its nutritive and economic value; emphasis is rather placed more on the production of yam and cassava. As a result, the study seeks to provide preliminary planning information for the project and also produce a suitability map showing areas that are suitable for the production of cocoyam in the study area in different classes

\section{LITERATURE REVIEW}

In several developing countries roots and tubers such as cocoyam (Colocasia esculenta and Xanthosoma Sagittifolium), yam (Dioscorea sp), cassava (Manihot esculenta) and sweet potato (Ipoema batatas) are important crops that generate income and provide food security for the populace. The population of Nigeria is growing to a noticeable degree, and in order to meet the increasing demand for food, the farming community has to produce more. In order to increase food production and provide food security, crops need to be grown in areas where they are best suited. In order to achieve this, the first and foremost requirement is carrying out land suitability analysis [4]. Land suitability analysis is a method of land evaluation, which measures the degree of appropriateness of land for a certain use. The analysis allows identification of the main limiting factors of crop production and enables decision makers to develop crop management system.

In Nigeria, cocoyam is cultivated predominantly as annuals, mainly for their edible starchy storage underground stems called corms and cormels, Nigeria maintains the lead among cocoyam producing nations, with an annual production of 4.55 million metric tonnes in 2012, representing 61.2 and $43.1 \%$ total production in West Africa and Africa, respectively. Despite the increasing importance of root crops such as cocoyam, yields still remain low in most countries [5]. In recent past, investment in the support services to Nigerian agriculture has been neglected with the result that this sector has not realized its full potential to contribute to the prosperity and economic development of the country. Meanwhile, increasing population pressure and the accompanying need to intensify agricultural production is leading to erosion of the natural resource base on which agriculture depends. The sustainability of production is threatened by a vicious cycle of declining soil fertility and increasing problems of pests, diseases, and weeds. Moreover, the lack of knowledge on how to add value through proper storage, processing, and marketing impedes agricultural growth.

The National Root Crops Research Institute (NRCRI), Umudike, launched Cocoyam Re-birth Initiative (CRI) in 2007 to increase awareness on nutritional, health and economic importance of cocoyam. [6]. The Cocoyam Re-Birth Initiative (CRI) is a typical example of strategies to reposition cocoyam as a major staple food and agro-industrial raw material in sub-Saharan Africa. At the end of the research, it was discovered that areas around Kaduna, Bauchi, Plateau, Adamawa and Niger States and parts of Kogi, Kwara, Benue, Plateau and Federal Capital Territory are moderately suitable for cocoyam production. The soils are fertile with a base saturation ranging from $60-80 \%$. [7].

Roots and tubers have been identified among the most important group of staple food in the Tropical world. Hahn observed that there would be more acute food deficit in the future unless the productivity of root and tuber crops is increased by at least three per cent per annum. There has been increased interest in root and tuber production due to increasing population, drought and scarcity of foreign exchange to import grains and flour into most African countries [8]. There has been growing concern about the capability of Nigerian agriculture to satisfy the food requirement of a fast-growing population, and to provide enough raw materials for the agro-based industries; more emphasis should be placed on production of root and tuber crops such as cocoyam [9].

\section{MATERIALS AND METHODS}

The methodology adopted in this study can be classified as follows: Identification of Soil types within the study Area, Classification of Land Use / Land Cover, Generation of Slope Using SRTM Data, and utilization of Suitability and Vulnerability Modelling and Computation Environment (SAVMACE) using Multi-Criteria Evaluation. Table 1 summarizes the data sets used in the study while the workflow diagram is shown in Figure 3 below 
Table 1: Data and Data Sources

\begin{tabular}{|l|l|l|l|l|l|l|}
\hline S/no & Data Type & Format & Scale & Resolution & $\begin{array}{l}\text { Acquisition } \\
\text { Date }\end{array}$ & Source \\
\hline 1 & Land-Sat ETM & Digital & & $30 \mathrm{~m}$ & 2014 & Earthexplorer.usgs.gov \\
\hline 2 & Soil Map & Analogue & $1: 1,300.000$ & & 1997 & Wageningen, The Netherlands \\
\hline 3 & SRTM & Digital & & $30 \mathrm{~m}$ & 2016 & Earthexplorer.usgs.gov \\
\hline
\end{tabular}

\subsection{Identification of Soil Types within the Study Area.}

This was done with the aid of the Soil map of Nigeria on the scale of 1:1,300.000 sourced from Wageningen, the Netherlands. The map was imported into ArcGIS (10.3) environment, it was geo-referenced, and the study area of interest (AOI) was digitized and delineated. The soil types that were identified and digitized include Acrisols, Alisols, Fluvisols, Gleysols, and Nitosols.

\subsection{Classification of Land Use and Land Cover within the Study Area.}

Classification of Land Use/ Land Cover was carried out using Land-Sat Image of $30 \mathrm{~m}$ resolution covering the study Area of Interest (AOI). The satellite image was layer stacked colour composite was done in order to assign different bands to the image in order to enhance clarity, the image was imported into Envi 4.3 environment where it was eventually classified. The image was further exported to ArcGIS 10.3 for further analysis.

The map was reclassified, and the various classes used for the study were ranked accordingly. These classes include settlement, bare surfaces, cultivated land, Shrubland, and wetland. And they were ranked 1,2,3,4, and 5 respectively according to their various significance. One has to be the least favourable and five been the most favourable.

\subsection{Generation of Thematic Maps}

Various thematic maps of the study were generated using ArcGIS 10.3. These thematic maps were rasterized and reclassified into five suitability classes based on the crop requirement using the spatial analyst tool in ArcGIS 10.3. They include soil map, slope and LULC map. The slope information was obtained from Digital Elevation Model (DEM) using GIS software package Arc GIS 10.3 derived from SRTM (Shuttle Radar Topographic Mission) data with $30 \mathrm{~m}$ spatial resolution. TIN to raster operation was carried out in spatial analyst tool in ArcGIS 10.3, and the slope was finally generated. The DEM and slope were also rasterized and reclassified into five suitability classes based on the crop requirement.

\subsection{Image Processing}

The land use land cover information was generated using the Land-Sat image acquired in 2014 with a spatial resolution of $30 \mathrm{~m}$ pixel size and processed using ENVI 4.3 and ArcGIS 10.3. Supervised classification was done using the maximum likelihood algorithm for 3 spectral bands corresponding to 5, 4, 3 combinations. Green, red, and blue (G, R, B). The image was exported to ArcGIS 10.3 after classification in Envi environment. The land use / land cover classes identified in the image was classified into five (5) basic features which include Wetland, Shrub land, cultivated land, bare surfaces, and Settlement using the land classification scheme described by a scholar [10].

\subsection{Suitability and Vulnerability Modelling and Computation Environment (SAVMACE)}

Based on a study, SAVMACE is a generic spatial decision support system that provides an environment for the modelling and computation of suitability and vulnerability scenarios [11]. It was used in this study to model the factors that contribute positively to the growth of cocoyam in the study area which includes soil, slope, and land use. Relative weights were assigned to the factors accordingly and used to produce the suitability map.

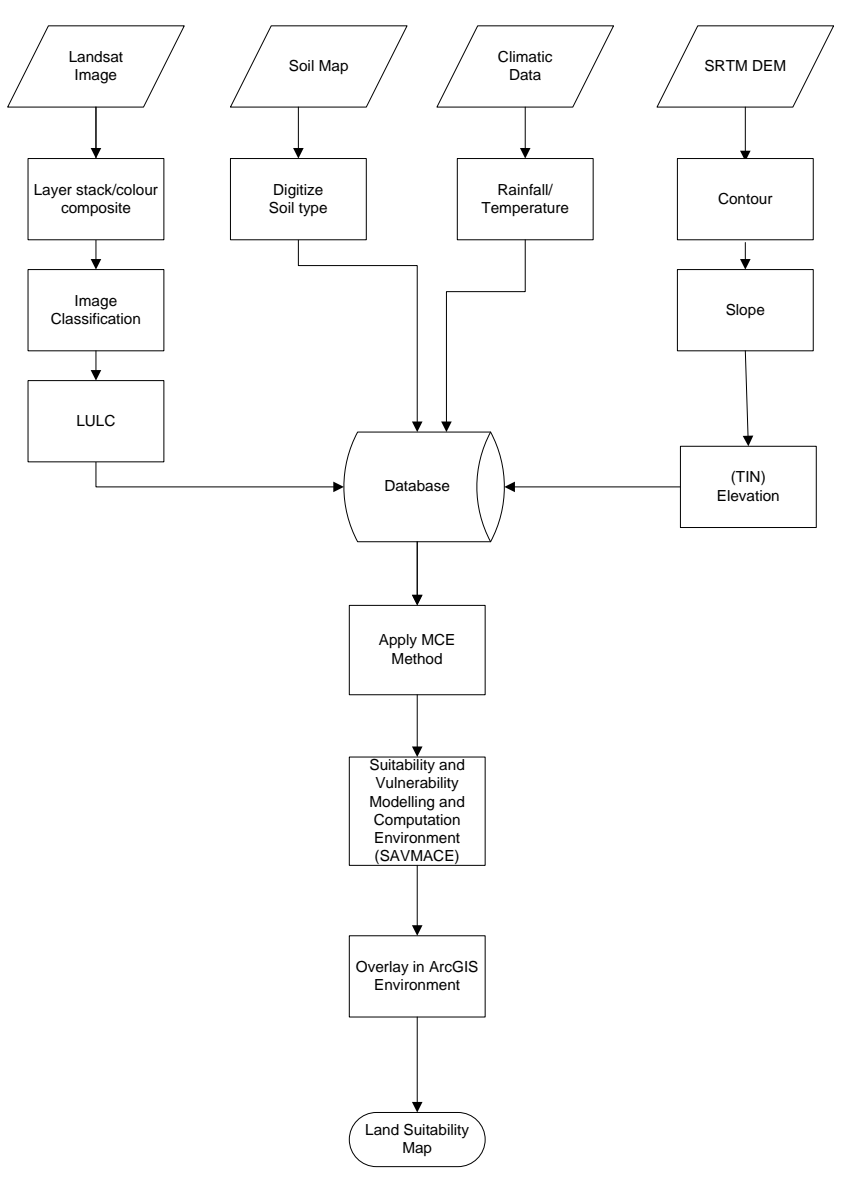

Figure 3: Methodological Flow Chart

\section{RESULT AND DISCUSSION}

Cocoyam suitability evaluation was carried out by first modelling the factors that contribute positively to the growth of the crop which includes soil, slope, and land-use, which were assigned relative weights of $0.5,0.3$, and 0.2 respectively. Soil types would define the nature of the medium in which the crop would grow, thus defining many important conditions such as nutrient availability and supply to the crop, soil aeration and waterretention capacity. The slope factor defines how steep the landscape is, thus affecting processes such as soil and nutrient erosion. The land-use factor is used to distinguish areas of potential and/or pre-existing crop cultivation from areas that cannot be used for crop cultivation. Rainfall was also considered in the study as a factor for the crop growth, but because the study area does not cover a national or regional scale, it is therefore assumed that the climatic condition of the small area covered is of a single type [12].

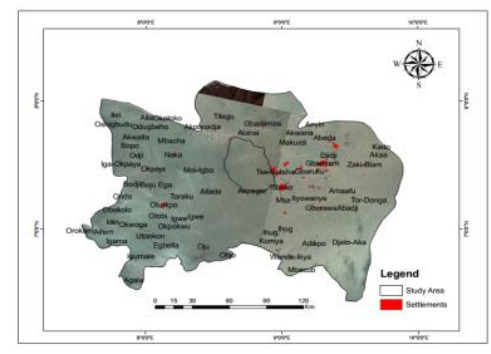

Figure 4: Land-Sat image of Benue State showing study area. 


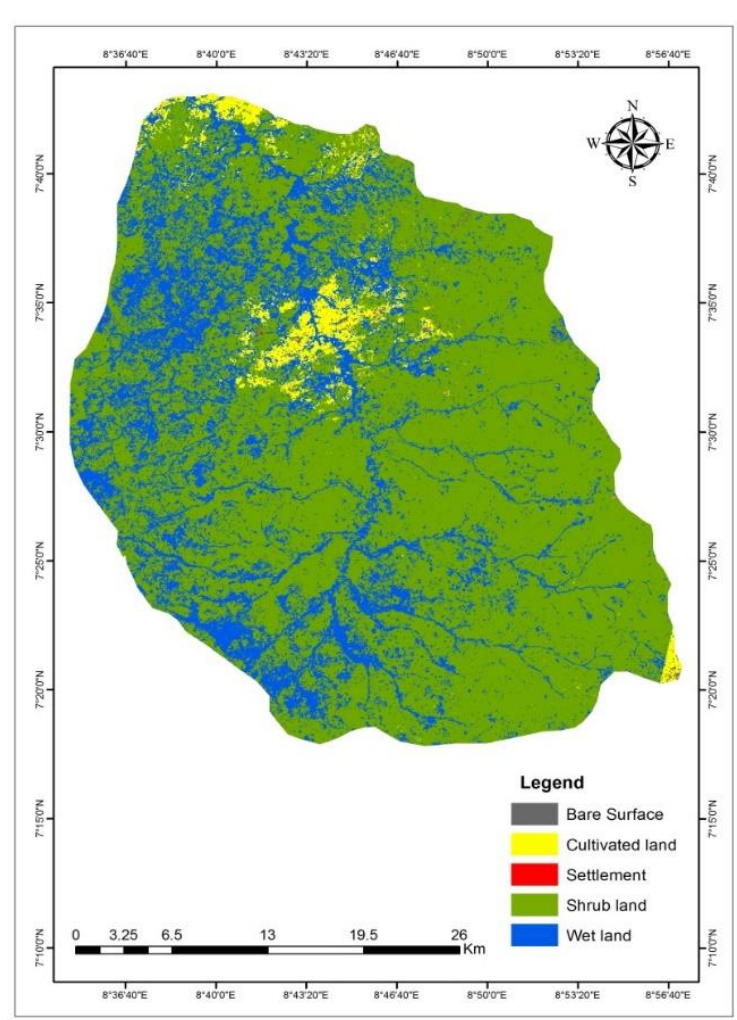

Figure 5: Classified satellite image of study area

Table 1: Land use Land cover Analysis

\begin{tabular}{lcc}
\hline & Area km $^{2}$ & (\%) \\
\hline Settlement & 0.2318 & 0.017269
\end{tabular}

\begin{tabular}{lll|}
\hline Bare-surface & 5.4180 & 0.403638 \\
\hline Cultivated land & 45.1564 & 3.364126 \\
\hline & & \\
\hline Wet land & 959.1650 & 71.45724 \\
\hline & 332.3210 & 24.75772 \\
\hline Total & & \\
\hline
\end{tabular}

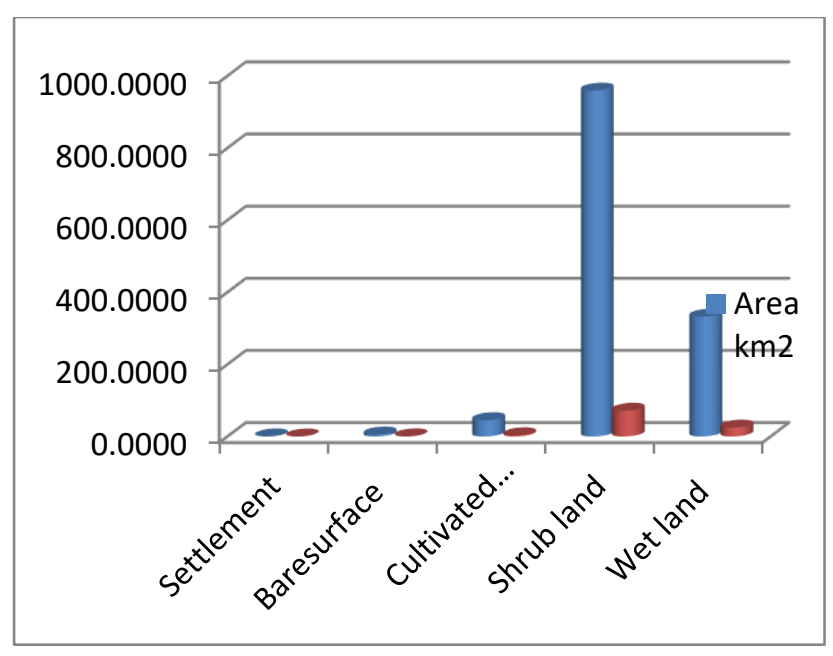

Figure 6: Area in $\mathrm{Km}^{2}$ and Percentage of Land use Land cover.
Table 2: Soil Analysis

\begin{tabular}{lll}
\hline Soil Types & Area $\mathbf{K m}^{\mathbf{2}}$ & $\mathbf{( \% )}$ \\
\hline Nitisols & 1149.75 & 85.66 \\
\hline Alisols & 20.59 & 1.53 \\
\hline Gleysols & 18.72 & 1.39 \\
\hline Fluvisols & 20.12 & 1.50 \\
\hline Acrisols & 132.99 & 9.91 \\
\hline Total & 1342.17 & 100.00 \\
\hline
\end{tabular}

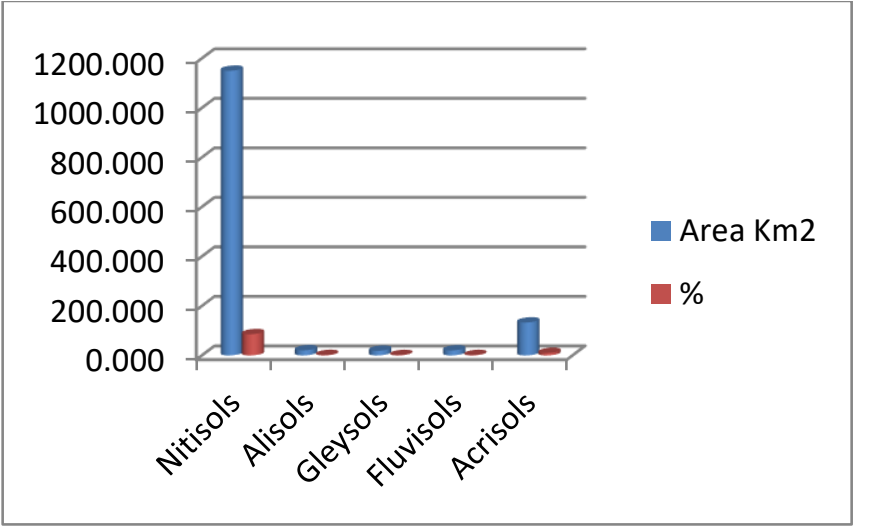

Figure 7: Area in $\mathrm{Km}^{2}$ and Percentage of Soil Types.

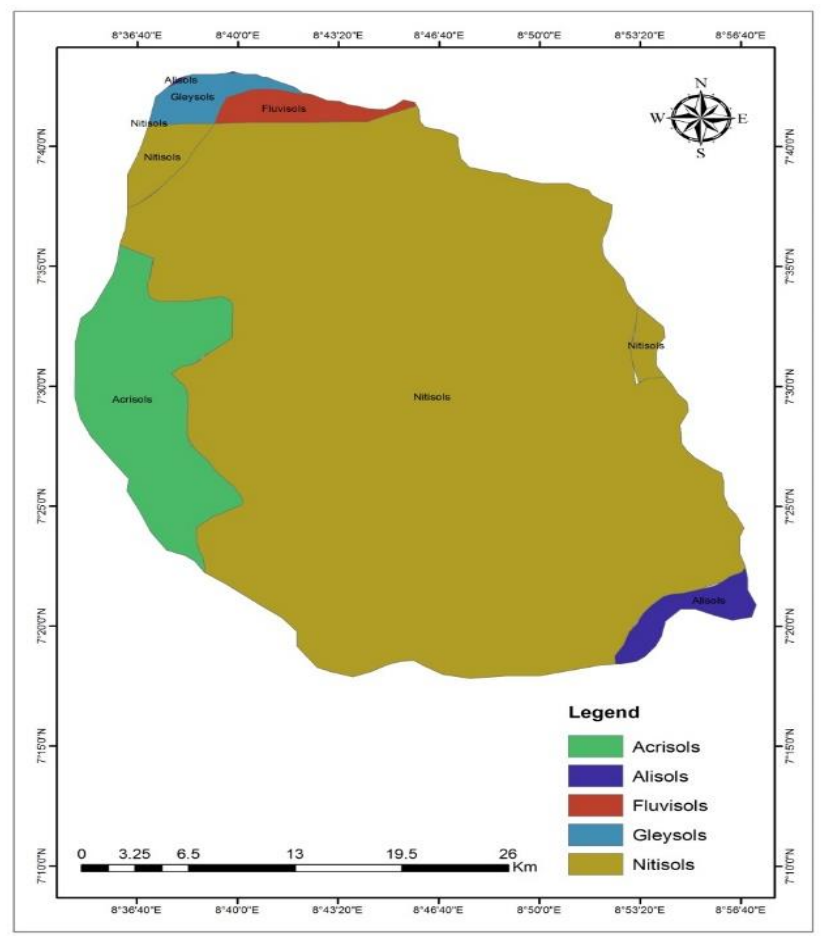

Figure 8: Soil Map of study area.

From the analysis above, the study shows that the delineated study area is predominantly covered with shrub land with about $959.1650 \mathrm{~km}^{2}$, representing $71.46 \%$, followed by wetland, cultivated land, bare surface and settlement with $332.3210 \mathrm{~km} 2,24.76 \%, 45.1564 \mathrm{~km}^{2}, 3.36 \%$, $5.4180 \mathrm{~km}^{2}, 0.40 \%$, and $0.2318 \mathrm{~km}^{2}, 0.02 \%$ respectively, Nitisol soil is the dominant soil type within the study area with a percentage of $85.66 \%$, 
followed by acrisols, alisols, fluvisols and then gleysols with a percentage of $9.91 \%, 1.53 \%, 1.50 \%$ and $1.39 \%$ respectively. This implies that Nitisol soils favour the production of cocoyam more than any other soil type within the study area as cocoyam can only thrive very well in a welldrained soil type. It produces optimum yields when planted in fertile soil with a good water retention capacity. Nitosols are well-drained soils with a clayey sub-surface horizon that is deeply stretched and has nutty or polyhedric blocky structure elements with shiny faces. Gleysols, on the other hand, are wetland soils that unless drained, are saturated with groundwater for a long period to develop a characteristic gleyic colour pattern. Gleysols are mostly planted to rice; it doesn't favour the production of cocoyam at all.

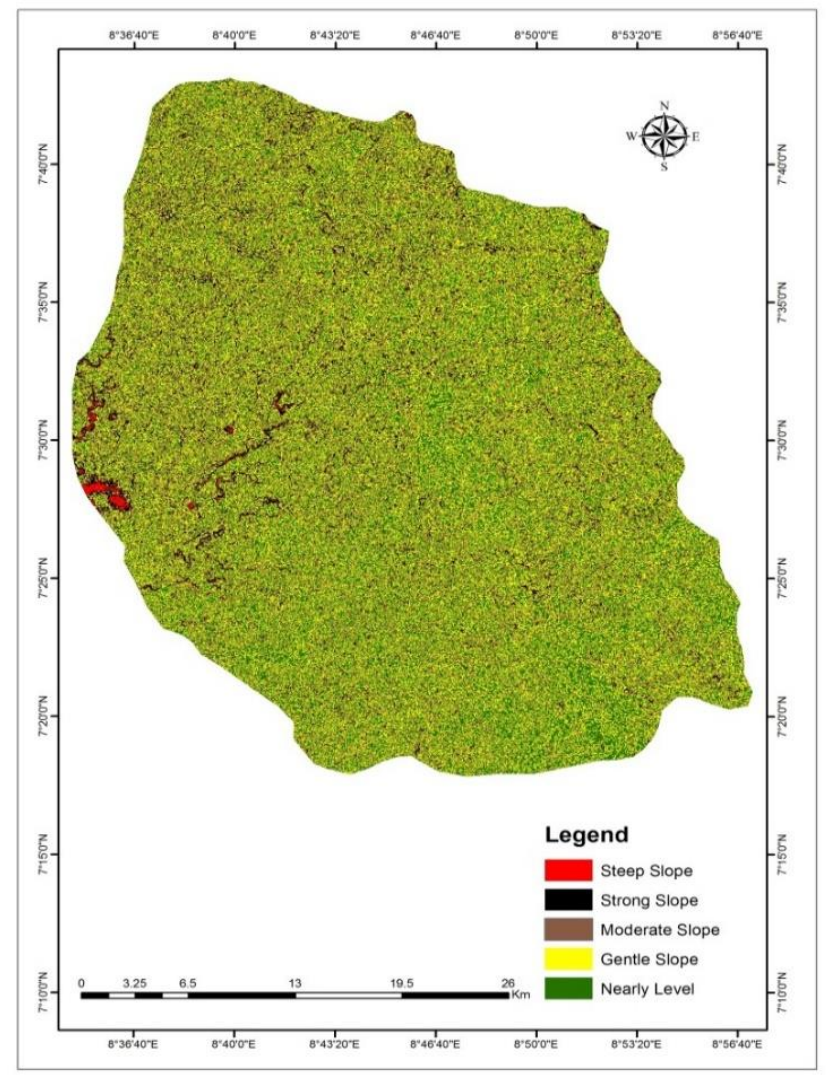

Figure 9: Slope Map of study area.

The study area shows that they are no adequate settlements within the area, this is because the area is mainly a basin, the area is relatively suitable for the cultivation of cocoyam except areas around Gwer-East LGA close to Moi-Igbo and Aliade all in Gwer-East LGA. Within these areas, you will find places of steep and strong slopes which are not suitable for cultivating cocoyam.

Table 3: Suitability Analysis

\begin{tabular}{lcc}
\hline & Area $\mathbf{K m}^{\mathbf{2}}$ & $\mathbf{( \% )}$ \\
\hline Highly Suitable & 400.38 & 29.88 \\
\hline Suitable & 537.30 & 40.10 \\
\hline Moderately Suitable & 389.05 & 29.04 \\
\hline Slightly Suitable & 10.96 & 0.82 \\
\hline Not Suitable & 2.23 & 0.17 \\
\hline Total & 1339.92 & 100.00 \\
\hline
\end{tabular}

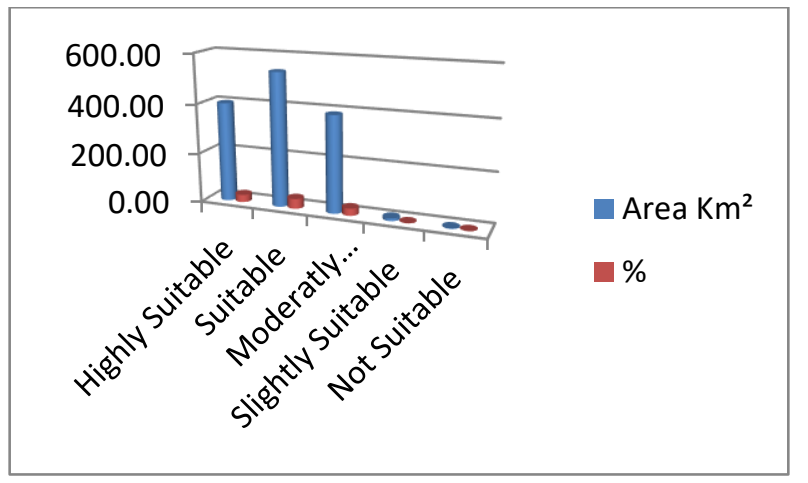

Figure 10: Area in $\mathrm{Km}^{2}$ and percentage for Suitability Analysis.

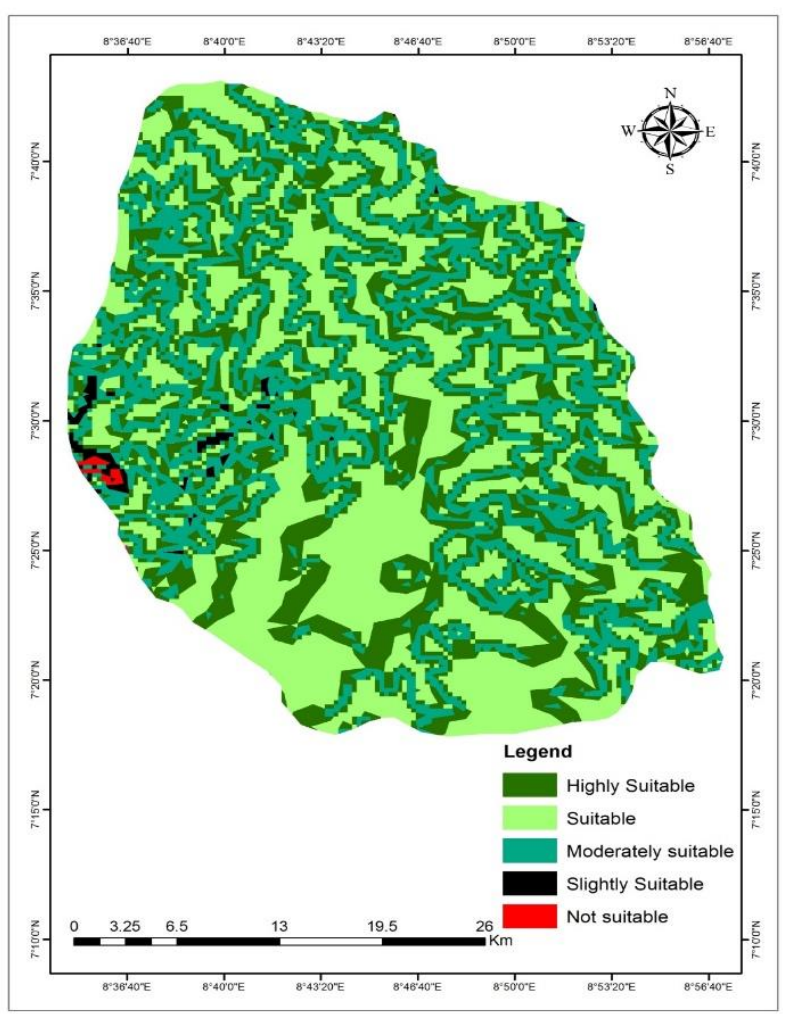

Figure 11: Cocoyam Suitability Map of Study Area

The modelling technique adopted in the suitability process here is Weighted Linear Combination (WLC) which makes use of factors and constraints in the multi-criteria modelling of the scenario. However, the suitability map was produced using Suitability and Vulnerability Modelling and Computation Environment (SAVMACE) where all the datasets were compressed in one single file, and then the suitability model was run to produce the final suitability map using the generated weightage for each factor. The results were updated to a newly created field in the attribute data of the GIS layer containing the entire factor data used for the suitability evaluation. After the computation, SAVMACE sent the results into ArcGIS for symbolization and visualization.

\section{CONCLUSION}

The results obtained from this study indicate that the use of remote sensing data and GIS application together with multi-criteria Evaluation using Suitability and Vulnerability Modelling and Computation Environment (SAVMACE) could provide a database for cocoa yam production. Although, cocoa yam is not really cultivated in the area but based on the findings in this study, it is recommended that cultivation of the crop should be carried out within the area and Benue State at large, where it's actually suitable in order to increase food production.

\section{REFERENCES}

[1] Halder, J.C. 2013. Land suitability assessment for crop cultivation by using remote sensing and GIS, Journal of Geography and Geology, 5(30), 65-74. 
[2] FAO Year Book. 1991.

[3] ODNRI. 1989. Nigeria profile of agricultural potential. Overseas Development Natural Resources Institute, United Kingdom, 15.

[4] Kihoro, J., Njoroge, J.B., Murage, H. 2013. Suitability analysis for rice growing sites using a multi-criteria evaluation and GIS approach in great Mwea region, Kenya, Springer Plus, 2, 265-274.

[5] Osagie, P.I. 1998. Transfer of root crop technology for alleviation of poverty: The contribution of shell, Nigeria. In: Akoroda, M.O. and Ekanayake, I.J. Proceedings of the Sixth triennial symposium of the international society for tropical Root crops, Malawi, 38-41.

[6] Kundu, N., Campbell, P., Hampton, B., Lin, C., Ma, X., Ambulos, N., Zhao, X.F., Goloubeva, O., Holt, D., Fulton, A.M. 2012. Antimetastatic activity isolated from Colocasia esculenta (taro). Anti-Cancer Drugs, 2, 200-211.

[7] Plucknett, D.L., de la Pena, R.S., Obrero, F. 1970. Taro (Colocasia esculenta). Field Crops Abstract, 23, 413-426.
[8] Hahn, S.K. 1994. Root crops for food security in Sub-Saharan African in Akoroda, M.O. Proceeding of the Fifth Triennial Symposium of the International Society for Tropical Root Crops, Uganda, 16-21.

[9] International Institute of Tropical Agriculture (IITA). 1996. Annual Report. International Institute of Tropical Agriculture, Ibadan Nigeria.

[10] Anderson, J.R., Hardy, E.E., Roach, J.T., Witmer, R.E. 1976. A Land Use and Land Cover Classification System for use with Remote Sensor Data. Washington, D.C., U.S. Geological Survey Professional Parer, 969.

[11] Babalogbon, B.A. 2013. A Multi-Criteria Spatial Decision Support for Generic Applications in Land Suitability Assessment for Crop Cultivation. M. Tech (GIT). Thesis Rectas.

[12] FAO. 1983. Guidelines: Land Evaluation for Rain fed Agriculture. FAO Soils Bulletin, 52, FAO, Rome, 237p. An Overview of Practical Applications of the FAO Approaches to the Evaluation of Land for Rain fed Cropping; provides also data on crop growth requirements for a wide range of crops.

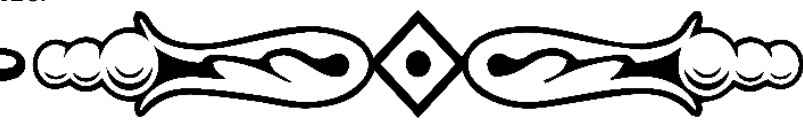

